\title{
Limb lengthening history, evolution, complications and current concepts
}

\author{
Gamal A. Hosny*
}

\begin{abstract}
Limb lengthening continues to be a real challenge to both the patient and the orthopaedic surgeon. Although it is not a difficult operative problem, there is a long and exhausting postoperative commitment which can jeopardize early good results. I aim to review the history, evolution, biology, complications and current concepts of limb lengthening. llizarov's innovative procedure using distraction histeogenesis is the mainstay of all newly developing methods of treatment. The method of fixation is evolving rapidly from unilateral external fixator to ring fixator, computer assisted and finally lengthening intramedullary nails. The newly manufactured nails avoid many of the drawbacks of external fixation but they have their own complications. In general, the indications for limb lengthening are controversial. The indications have been extended from lower limb length inequality to upper extremity lengthening, including humeral, forearm and phalangeal lengthening. A wide range in frequency of complications is recorded in the English literature, which may reach up to $100 \%$ of cases treated. With developing experience, cosmetic lengthening has become possible using external or internal lengthening devices with an acceptable rate of problems.
\end{abstract}

Level of evidence: $\mathrm{V}$.

Keywords: Limb lengthening, Indications, Achondroplasia, Cosmetic lengthening, Upper extremity lengthening

\section{Introduction and history}

Alessandro Codivilla of Bologna was the first to apply skeletal traction for bone lengthening. He used acute forced lengthening for short distances under narcotics. He described another technique for larger distances by continuous extension, using distraction with a calcanean pin and oblique osteotomy, followed by traction of $25-30 \mathrm{~kg}$. More lengthening can then be achieved by applying more traction in stages [1]. One-stage lengthening was developed by Fassett using an osteotomy, inserting a bone graft and fixating with a plate. However, this procedure was followed by many serious complications [2].

In 1932, Abbot presented his experience with lower limb lengthening of 73 patients (45 tibial lengthenings) at the Shriners' Hospital for Crippled Children in St. Louis.

\footnotetext{
*Correspondence: gamalahosny@yahoo.com

Benha University Hospitals, 11 Al Israa Al-Mohandeseen Street, Cairo, Egypt
}

The basic principles stated in this paper were traction and counter traction through the bone, slow continuous traction to overcome the resistance of the soft tissues and accurate contact and alignment of bone ends. $\mathrm{He}$ described in detail the basic principles of tibial lengthening, including the application of two pins above and below the osteotomy, connected to a special apparatus. The drill pins were made of stainless steel, not ordinary steel, as it is less irritating to the soft tissues. The operative steps were: lengthening of the Achilles tendon, osteotomy of the fibula, insertion of the pins, application of the apparatus, osteotomy of the tibia and closure of the wound with drainage. Tibial osteotomy had to be performed with minimal soft tissue dissection to keep the blood supply to the bone and guard against infection. The surgeon had to wait for 1 week until the swelling had gone down before distraction. This was the first description of the waiting period before the Ilizarov era. The average distraction rate was $1.6 \mathrm{~mm}$ per day and the period of traction was 4 to 5 weeks. The apparatus was kept in place for 8 to 
10 weeks followed by removal and application of a plaster cast. Follow-up X-rays were taken every 2 to 3 weeks to check the bone formation. The age of patients ranged from 8 to 19 years. The magnitude of tibial lengthening ranged from 3.81 to $8.89 \mathrm{~cm}$. They reported excellent results with tibial lengthening but less favourable results with the femur and a higher rate of complications [3]. Then, Dickson and Diveley reported on an apparatus that used Kirschner wires rather than larger diameter pins to minimize soft tissue damage [4]. The method developed by Wagner gained popularity in Europe and the US; the method consisted of 3 operations. The first operation was the application of unilateral external fixation and a diaphyseal osteotomy. There was no waiting period, so acute operative lengthening for $5 \mathrm{~mm}$ was performed, followed by daily distraction of about $1.5 \mathrm{~mm}$. The second operation was plating and bone graft. The third operation was plate removal and casting. However, a high rate of complications was recorded $[5,6]$.

Most of our contemporary knowledge of bone lengthening comes from the Ilizarov method. Ilizarov started his work in 1951 by treating a patient with a bone defect using a circular frame and transfixation tensioned wires. Then he discovered the biological law of tension stress or distraction histeogenesis and applied this principle to treat a wide variety of conditions such as nonunion, osteomyelitis, dwarfism, congenital deformities, some bone tumours, bone defects, fractures and bone shortening [7]. Recently, hexapodal computer assisted circular frames such as the Taylor Spatial Frame have gained in popularity. The next step in development was the application of self distraction motorized nails (a magnetically driven, titanium intramedullary nail) to avoid the complications of external fixation and gain rapid rehabilitation. However, Ilizarov's principles still are the cornerstones of all bone lengthening procedures.

\section{Biology of limb lengthening}

The current basic principles of bone lengthening are derived from the general biological law of tension stress. Gradual traction on living tissues creates stresses that can stimulate and maintain the regeneration of active growth of certain tissues. With adequate blood supply, steady gradual traction of the tissues activates proliferative and biosynthetic functions. The regeneration develops along the axis of the applied traction (Fig. 1). Experimental studies revealed the importance of soft tissue preservation during corticotomy and fixator stability, and the osteogenic power in the regeneration area depends upon the degree of bone marrow damage, periosteum and nutrient vessels. With distraction, new blood vessels develop in the transverse

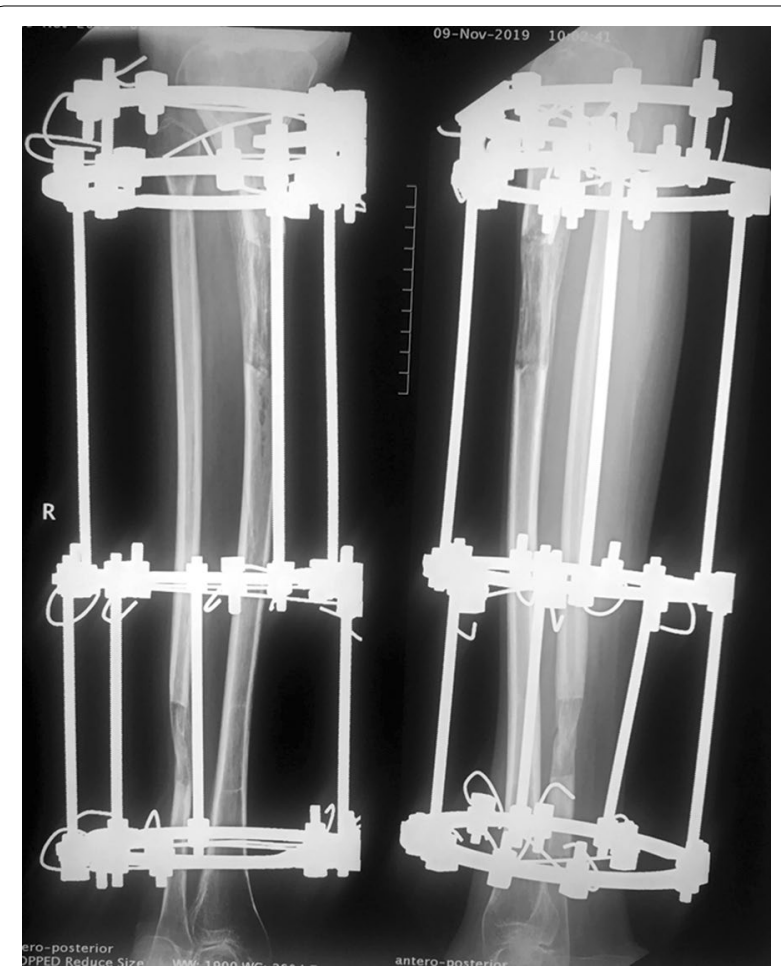

Fig. 1 Tibial lengthening case showing that the regeneration develops along the axis of the applied traction

or longitudinal direction according to the tension vector. Under the tension-stress effect neovascularization occurs not only in bone but also in the soft tissue [8-10].

The biology of bone lengthening includes 3 stages: the latency phase, the distraction phase and the consolidation phase (Fig. 2). The process starts with a corticotomy, which is similar to a closed low-energy fissure fracture, and secure fixation of the two ends. Distraction can be of the callus or physis according to the site of application of the tension-stress effect [11].

The action of all types of external fixators, whether unilateral or circular, and internal medullary lengtheners, are based upon the law of tension stress [12, 13].

Stimulation of the regeneration area by systemic or local measures has been the mainstay of experimental and clinical research to enhance callus formation and decrease the time the fixator needs to remain in place. Systemic administration of bisphosphonates, high doses of alendronates, calcitonin and nerve growth factor have been administered in experimental trials with variable degrees of success. Local augmentation using a wide range of cells and growth factors such as BMP-2 and BMP-7, TGF-B, platelet rich plasma and stem cells is being researched [14]. 

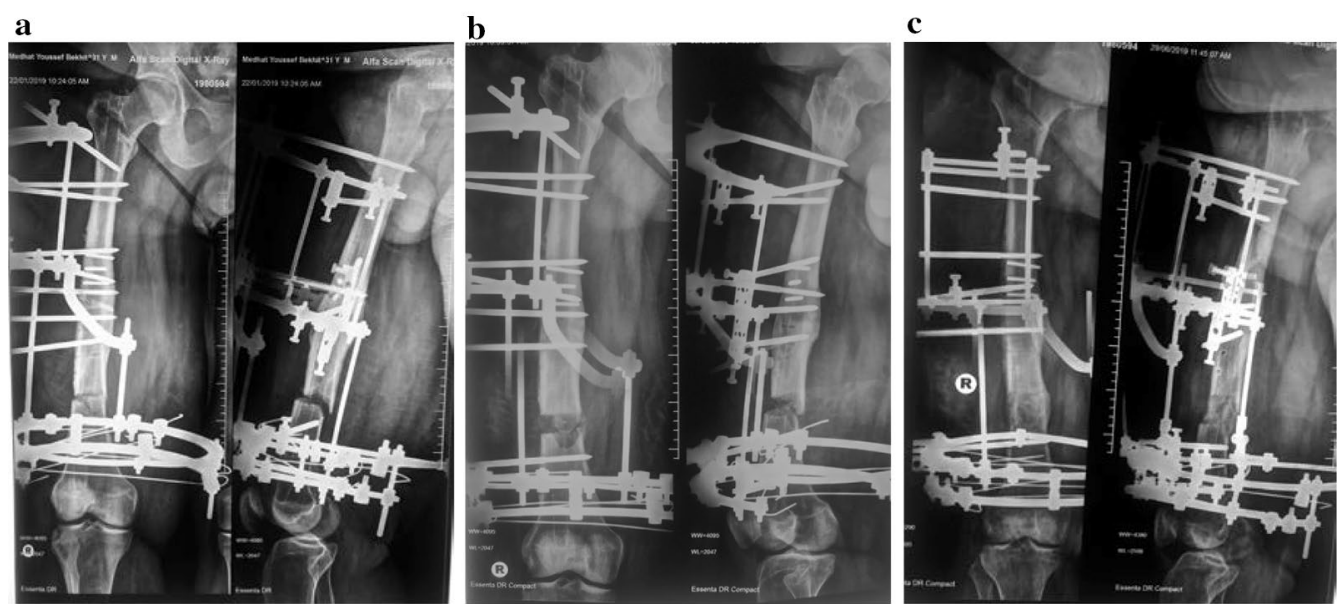

Fig. 2 a Femoral lengthening case during the latency phase after corticotomy. b Distraction phase. c Consolidation phase

\section{Evolution of bone lengthening devices}

Limb lengthening devices have evolved in the last 100 years. The first trials just used skeletal traction. The unilateral fixator was the standard method of fixation for a long time. The advances in fixator design included the application of half pins in more than one plane and addition of hinges which allowed joint movement during distraction [15-18]. Then, with the advent of Ilizarov's revolutionary ideas, the principle of the circular fixator spread all over the world. The invention of the hexapodal frame had similar results and introduced the ability of lengthening and managing all deformities simultaneously without the need to change the frame. Computer assisted correction with the Taylor Spatial Frame, which is formed of two rings and six struts (each one connected with two universal hinges), was a real step forwards in improving the accuracy of lengthening and deformity correction [19]. In order to shorten the external fixation period, other methods were developed, such as lengthening over a small diameter nail and lengthening followed by nailing or plating. In children, flexible intramedullary nails were used to avoid physeal injuries. Over time, the incidence of fracture in the regenerated bone after removal of external fixation was reduced [20-23]. Finally, in the last two decades, internal bone lengthening nails without the need for external fixation have become popular. The Albizzia nail was designed by Guichet; it has a ratchet assembly and limb rotation is required to induce distraction [24]. In the United States, the ISKD (Intramedullary Skeletal Kinetic Distractor) was cleared for marketing in 2001. However, follow-up revealed a high rate of complication due to uncontrolled distraction and it was withdrawn from the market $[15,25,26]$. Currently, the motorized lengthening nails Fitbone and
PRECISE, which do not require rotation for distraction, are becoming popular [27-31].

\section{Indications for limb lengthening}

In general, the indications for limb lengthening are controversial. Classic teaching classifies shortening into 3 categories: less than $2 \mathrm{~cm}$, which can be ignored; $2-4 \mathrm{~cm}$, with the possibility of lengthening; and more than $4 \mathrm{~cm}$ where lengthening is needed to avoid possible complications of lower limb length inequality such as pelvic obliquity and scoliosis. Also, a discrepancy of about $5 \mathrm{~cm}$ between leg lengths can be treated by epiphysiodesis in growing legs, or shortening of the longer leg at an appropriate time. However, this classification did not take into consideration the patient's height, heel size, tolerability of the shoe lift, family opinion and psychological aspects. With growing experience of the new advances in limb lengthening, these factors usually play an important role in decision making $[32,33]$. The aetiology of bone shortening and associated deformities is important for planning. The cause may be congenital deficiencies such as fibular hemimelia (Fig. 3), tibial hemimelia or congenital short femur, old poliomyelitis, bone tumours such as hereditary multiple exostosis [34] or past trauma. Bilateral lengthening may be indicated in cases of dwarfism caused by achondroplasia, especially if it is accompanied by deformities such as genu varum.

\section{Complications}

Results of limb lengthening are significantly affected by the clinical experience of the operating surgeon [35]. Perhaps this is what causes the wide range of frequency of complications in the English literature. Even the classification of the type of complications varies widely, whether 

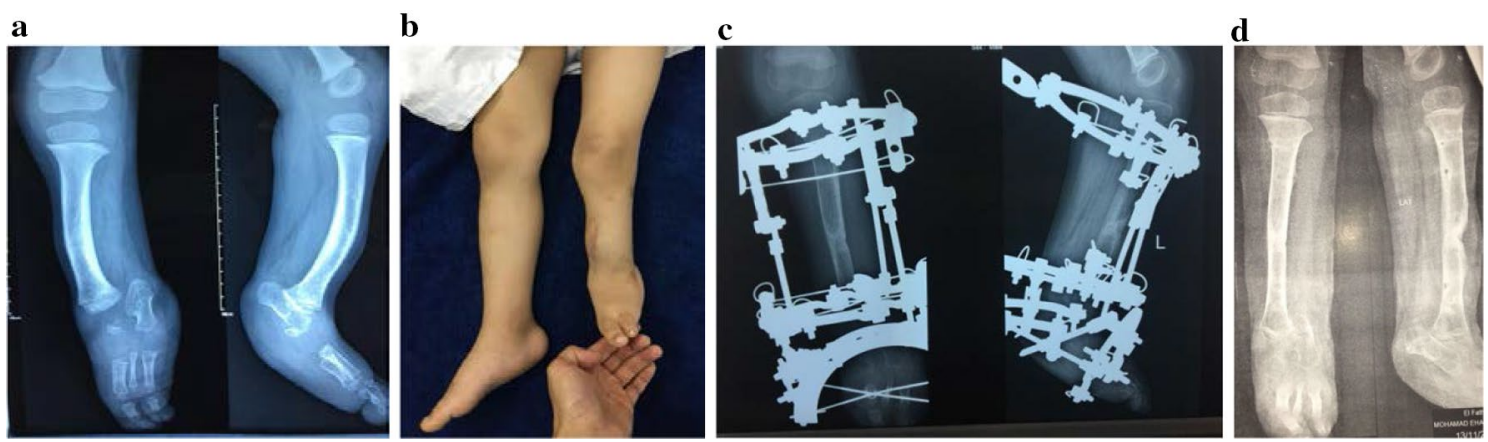

Fig. 3 a A 3-year-old boy, fibular hemimelia, tibial shortening and angulation. b Clinical photo. c Picture at the end of lengthening and deformity correction. $\mathbf{d}$ Picture after fixator removal

major or minor, simple or complicated, or affecting the final outcome [36, 37]. Many reports describe relatively small numbers of patients operated on by many surgeons with variable clinical experience over long time periods and sometimes in many centres [38-41]. It is difficult to reach valid conclusions when only a few patients are operated on every year (Table 1) [26, 36, 38-43]. The Ilizarov method causes postoperative, not operative, problems. The patient may stay in the frame more than 1 year. Most teaching courses and programmes only teach frame application, which is just the start in a long course of treatment.

The most common complication of external fixation is pin track infection, with a variable incidence which may reach $100 \%$ of treated patients. There are many variables which affect the frequency of this complication, such as duration of fixation, material of the wires or half pins, surgical procedure and wound care. Many pin site care programmes are designed to prevent the development of infection but are not supported by reliable evidence. Treatment usually starts with oral antibiotics and increasing the frequency of pin site cleaning in mild cases and ending up with removal of the pin in severe cases. The use of hydroxyapatite coated pins can reduce the incidence of pin site infection significantly [44].

Poor regeneration is a serious problem during limb lengthening and results from many systemic or local causes. It is important to modify the rate and frequency of distraction according to regeneration. Once delayed regeneration has been diagnosed, alternate cycles of compression distraction can solve the problem [45].

Axial malalignment can develop with distraction as there is variable resistance of the different muscles surrounding the limb (Fig. 4). This can be corrected by changing the connecting rods of the construct in the outpatient clinic, using hinges. Joint subluxation or dislocation is a serious complication with increasing likelihood with unstable joints such as in congenital shortening. Management of joint abnormality or instability has to precede lower limb lengthening, and sometimes extending the frame to cross over the joint can guard against the development of this complication; however, this increases

Table 1 Overall complication rate during lengthening

\begin{tabular}{|c|c|c|c|c|c|}
\hline Study & Procedure & No. of patients & Period of study & Complication rate & No. of surgeons \\
\hline Bukva et al. [38] & IEF or IEF\& IA & 73 & 14 years & $83.6 \%$ & Single \\
\hline Lascombes et al. [36] & Multiple & 32 & 3 years & $75 \%$ & Multiple \\
\hline \multirow[t]{3}{*}{ Lee et al. [68] } & ISKD & 35 & 2 years & $74 \%$ & Single \\
\hline & PRECICE 1 & 34 & Not available & $17.4 \%$ & Single \\
\hline & PRECICE 2 & 64 & Not available & $50 \%$ & Single \\
\hline Castelein and Decquer [39] & & 39 & 14 years & $84 \%$ & Multiple \\
\hline Reitenbach et al. [40] & TSF \& IEF & 43 & 16 years & $\begin{array}{l}\text { TSF } 12.1 \% \\
\text { IEF 50\% }\end{array}$ & Multiple \\
\hline Manggala et al. [41] & TSF \& IEF & 14 & 4 years & $\begin{array}{l}\text { TSF } 28.6 \% \\
\text { IEF } 71.4 \%\end{array}$ & Multiple \\
\hline Guerreschi and Tsibidakis [43] & $\mathrm{IEF}$ & 63 & 25 years & $81 \%$ & Multiple \\
\hline Novikov et al. [42] & IEF & 138 & 23 years & $37 \%$ & Multiple \\
\hline
\end{tabular}

IEF Ilizarov external fixator, IA intramedullary alignment, ISKD Intramedullary Skeletal Kinetic Distractor, TSF Taylor Spatial Frame 


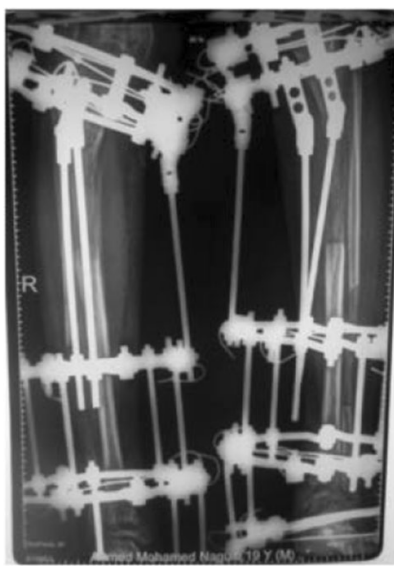

Fig. 4 Malalignment of the tibia during distraction and application of hinges to correct it

the possibility of stiffness. Premature consolidation of the regenerated bone has been reported due to irregular distraction of the osteotomy, especially in children. The treatment may be re-osteotomy or continuation of the distraction until the building force exceeds the resistance of the consolidation and the osteotomy opens once again, with severe pain. The resultant gap has to be closed and distraction starts again after a few days.

The incidence of complications is affected by the aetiology of the shortening and magnitude of the regenerated area. Extensive bone lengthening can adversely affect growth in children and increase the possibility of joint contractures [46, 47].

\section{Achondroplasia}

Achondroplasia is the most common skeletal dysplasia characterized by disproportionate dwarfism. The strategy of lengthening may be transverse, including both tibias, or both femurs, in each stage $[48,49]$. Most authorities adopt the transverse strategy as the patient can stop lengthening at any stage of treatment. The deformities seen in achondroplasia can be corrected simultaneously; lumbar hyperlordosis with an extension osteotomy of the femur, varus deformity of the leg, and a disproportionately long fibula may be reduced to normal length during the lengthening process.

The soft tissues in achondroplasia are usually redundantly long [50]. The magnitude of lengthening usually ranges between 25 and $30 \mathrm{~cm}$ which can be gained after stages or extensive lengthening. In cases with knee and ankle deformities, bifocal tibial lengthening (Fig. 3) can restore the normal mechanical axis and achieve more lengthening with less time in the fixator [51-53]. In our institution, our protocol starts early, between 4 and 6 years, by differential tibial lengthening for a short distance to correct the varus deformity and get the fibular head in position with indirect tightening of the lateral ligament. Femoral lengthening is performed between 9 and 11 years. Then another tibial lengthening (mostly bifocal) starts at age 13-14. Finally, humeral lengthening is done at an age of 15 or 16 . However, many patients are referred to our institution late and consequently we cannot follow this protocol (Fig. 5).

\section{Cosmetic lengthening}

Bone lengthening for aesthetic reasons for normal or short stature has been reported recently. The ethical principles and psychological factors have to be taken into consideration. Psychiatric evaluation is mandatory for all patients to exclude body dysmorphic disorder [54]. It is mandatory to have detailed preoperative psychological analysis to rule out any psychiatric illness which might affect the patient's ability to make a sensible decision. A single counselling session of limited time may not be enough to have fair appraisal of patient sanity. It would be wise to arrange several meetings between the patient
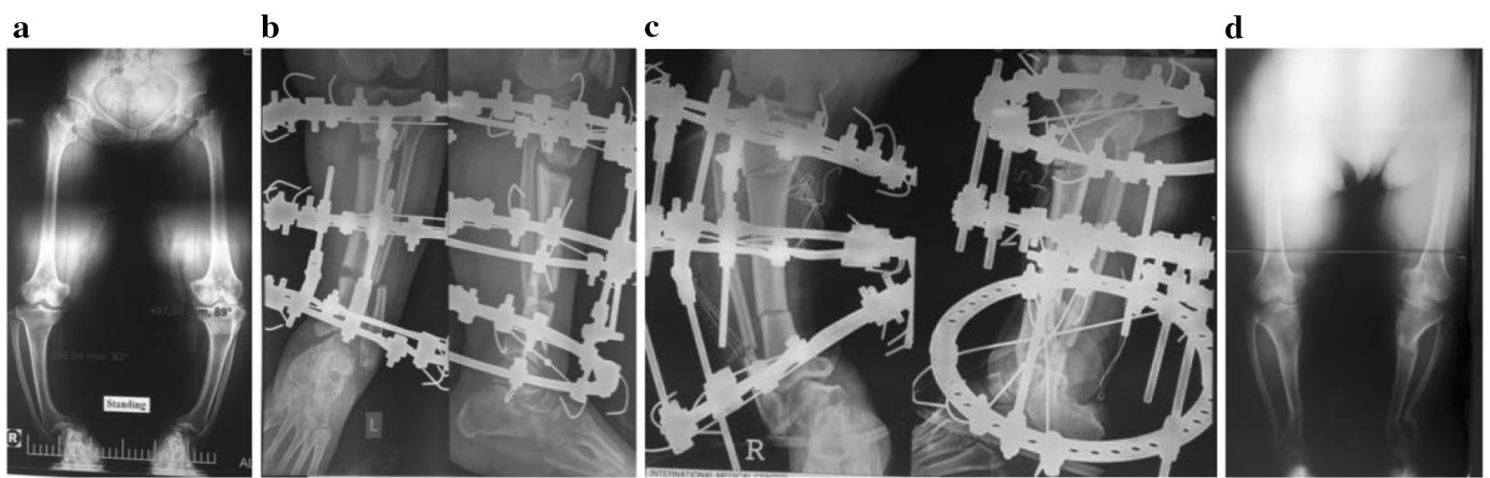

Fig. 5 a 53-year-old female with achondroplasia with knee and ankle deformities. b Bifocal corticotomy and application of llizarov Frame on the left side. c Bifocal corticotomy and application of Ilizarov Frame on the right side. $\mathbf{d}$ After fixator removal 

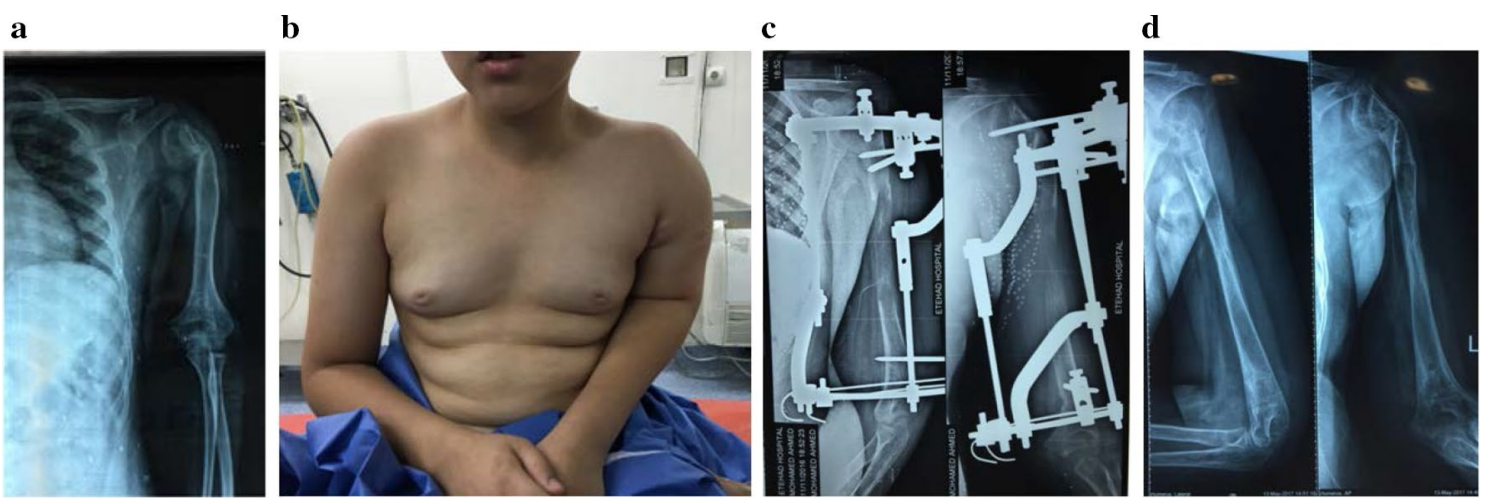

Fig. 6 a A 12-year-old boy with 10-cm post-traumatic humeral shortening. b Clinical photo showing left humeral shortening. c Plain X-ray at the end of distraction. $\mathbf{d}$ Plain $\mathrm{X}$-ray after fixator removal

and previously treated patients as part of the preoperative preparation programme to give them a real example of the difficulties to be expected before reaching their goal [55].

The first method used for cosmetic limb lengthening was the Ilizarov method, with a high rate of self satisfaction and improved level of social activities (96.7\% of patients) [56]. Bilateral tibial lengthening, monofocal or bifocal, was the most common procedure, with a few cases having femoral lengthening as well. Trunk limb proportions may limit the magnitude of lengthening to 5-7 cm. In 2014, Novikov et al. published the largest series of cosmetic lower limb lengthening treated by Ilizarov apparatus at the Ilizarov institute, including 131 patients. The ages of patients ranged from 16 to 67 years, with a mean lengthening of $6.9 \mathrm{~cm}$. At last follow-up there was one poor result $(0.77 \%)$ with a rate of complications about $37 \%$ [42]. The authors were able to manage most of the complications successfully without affecting the final results. However, the patients were kept in the hospital for the whole period of treatment, allowing close monitoring and early management, which is not available in other institutions [55]. The time in the fixator was reduced by using the lengthening over nail technique with a rather moderate rate of complications [57, 58]. Intramedullary limb lengthening has developed as an alternative to external fixation which is quite attractive to patients; it has a lower rate of complications and higher costs [30]. Recently, there has been a considerable desire for cosmetic lengthening surgery around the world. In spite of the extensive experience of the treating surgeon, many soft tissue and bone problems are possibly expected. Safety of the patient has to be more important than gaining more length [42]. For example, if a weak regeneration zone develops, which is not responsive to cycles of compression distraction, the surgeon has to reduce the expected area of lengthening by gradual compression to improve the regeneration and avoid nonunion. In our opinion we think that this procedure has to be undertaken by a surgeon with great experience in the field to handle the potential complications.

\section{Upper extremity lengthening}

There are few indications for upper extremity lengthening, but they include achondroplasia, hereditary multiple exostosis with shortening of the forearm bones, physeal growth arrest, amputation, infection and shortening from trauma. The reason upper extremity operations are not attempted as often as lower extremity operations might be due to reports of a high rate of complications and the possibility of functional deterioration [59,60]. However, with developing experience we think that bone lengthening has no harmful effect on the upper extremity. Hybrid fixation minimizes the incidence of neurovascular injury (Fig. 6). Increasing the magnitude of lengthening in the lower limb more than $20 \%$ of the original bone length mostly raises the incidence of complications. However, we did not face this problem with lengthening up to $100 \%$ of the limb length in upper extremities. Preoperatively, there was some sort of abnormality of the shoulder joint as dysplasia of the articular surfaces in unilateral cases which did not affect the final outcome. Bracing for 1 month after fixator removal was advised to guard against fracture of the regenerated bone [61, 62]. Intramedullary lengthening nails were successfully applied for humeral lengthening in 6 cases [63]. The primary indication for forearm lengthening is discrepancy between the radius and ulna, congenital longitudinal deficiency and trauma. The rate of distraction has to be modified according to the degree of regeneration to avoid the reported complication of delayed bone formation $[64,65]$. There are a few papers in the English literature 
reporting a small number of cases of short bone lengthening. Distraction histeogenesis (callotasis) was applied in a single stage and gradual lengthening for congenital and traumatic phalangeal shortening or amputation was achieved with excellent outcomes [66]. Two-stage treatment was also used including osteotomy and gradual distraction followed by bone graft [67].

\section{Conclusions}

Limb lengthening is a rapidly developing field of orthopaedic surgery. Currently it is a standard procedure with predictable results, and indications have been extended to include the upper extremities and cosmetic lengthening. I think experience has a great impact on the results of the different procedures because follow-up and management of expected complications are cornerstones of treatment strategy. Unfortunately, the English literature has many papers with relatively small numbers of patients operated on by many surgeons over a long period. This means that the experience of the individual surgeon is based on only one or a few cases per year. Sometimes it is difficult to get valid conclusions from the reported mixed data. In spite of the introduction of the promising intramedullary lengthening nails and computer assisted external fixation, we still count on Ilizarov's biologic laws. Advances through research to stimulate regeneration and reduce the period of treatment will be the real revolution in limb lengthening surgery.

\section{Acknowledgements}

None.

\section{Authors' contributions}

This is a single author paper. So, all the steps of writing the paper were done by him. The author read and approved the final manuscript.

\section{Funding}

None.

Availability of data and materials

Not applicable.

Ethics approval and consent to participate

Not applicable.

\section{Consent for publication}

The author gives his consent for publication.

\section{Competing interests}

The author declares no competing interests.

Received: 26 August 2019 Accepted: 29 December 2019 Published online: 05 March 2020

\section{References}

1. Jordan CJ, Goldstein RY, MCLaurin TM, Grant A (2013) The evolution of the llizarov technique Part 1: The history of limb lengthening. Bull Hosp Joint Dis 71(1):89-95
2. Fassett $F$ (1918) An inquiry as to the practicability of equalizing unequal legs by operation. Am J Orthop Surg 16:277

3. Abbott LC (1932) Lengthening of the lower extremities. Calif West Med. 36(1):6-13

4. Dickson FD, Diveley RL (1932) A new apparatus for the lengthening of legs. J Bone Jt Surg Am 14:194-196

5. Wagner H (1971) Operatice Beinverlangerung. Der Chirurg. 6:260-266

6. Birch JG (2017) A brief history of limb lengthening. J Pediatr Orthop 37:S1-S8

7. Gubin AV, Borzunov DY, Marchenkova LO, Malkova TA, Smirnova IL (2016) Ilizarov to bone reconstruction: historical achievements and state of the art. Strateg Trauma Limb Reconstr 11:145-152

8. Ilizarov GA (1992) Transosseous osteosynthesis. Theoretical and clinical aspects of the regeneration and growth of tissue. Springer, Berlin

9. Ilizarov GA (1989) The tension-stress effect on the genesis and growth of tissues: Part II. The influence of the rate and frequency of distraction. Clin Orthop Relat Res (239):263-285

10. Ilizarov GA (1989) The tension-stress effect on the genesis and growth of tissues. Part I. The influence of stability of fixation and soft-tissue preservation. Clin Orthop Relat Res (238):249-281

11. Hvid I, Horn J, Huhnstock S, Steen H (2016) The biology of bone lengthening. J Child Orthop 10:487-492

12. Chhikara N, Shaik S, Bhargava S (2018) Review on distraction osteogenesis: a boon to maxillofacial reconstruction. Int J Appl Dent Sci 4(2):44-48

13. Gubin AV, Borzunov DY, Malkova TA (2013) The llizarov paradigm: thirty years with the llizarov method, current concerns and future research. Int Orthop 37:1533-1539

14. Compton J, Fragomen A, Rozbruch R (2015) Skeletal repair in distraction osteogenesis: mechanisms and enhancements. JBJS Rev 3(8): $22: 1-12$

15. Lobst C (2015) Advances in pediatric limb lengthening, Part 1. JBJS Rev $3(8): e 3: 1-9$

16. Noonan KJ, Leyes M, Forriol F et al (1998) Distraction osteogenesis of the lower extremity with use of monolateral external fixation. A study of two hundred and sixty-one femora and tibiae. J Bone Jt Surg Am 80:793-806

17. Price CT, Mann JW (1991) Experience with the orthofix device for limb lengthening. Orthop Clin N Am 22:651-661

18. Donnan LT, Saleh M, Rigby AS (2003) Acute correction of lower limb deformity and simultaneous lengthening with a monolateral fixator. J Bone Jt Surg Br 85:254-260

19. Fadel M, Hosny G (2005) The Taylor spatial frame for deformity correction in the lower limbs. Int Orthop 29:125-129

20. Paley D, Herzenberg JE, Paremain G et al (1997) Femoral lengthening over an intramedullary nail. A matched-case comparison with llizarov femoral lengthening. J Bone Jt Surg Am 79:1464-1480

21. Rozbruch SR, Kleinman D, Fragomen AT, llizarov S (2008) Limb lengthening and then insertion of an intramedullary nail: a case-matched comparison. Clin Orthop Relat Res 466(12):2923-2932 (Epub 2008 Sep 18)

22. Oh CW, Song HR, Kim JW, Choi JW, Min WK, Park BC (2009) Limb lengthening with a submuscular locking plate. J Bone Jt Surg Br 91(10):1394-1399

23. Popkov D, Popkov A, Haumont T, Journeau P, Lascombes P (2010) Flexible intramedullary nail use in limb lengthening. J Pediatr Orthop 30(8):910-918

24. Guichet JM, Deromedis B, Donnan LT, Peretti G, Lascombes P, Bado F (2003) Gradual femoral lengthening with the Albizzia intramedullary nail. J Bone Jt Surg Am 85(5):838-848

25. Kenawey M, Krettek C, Liodakis E, Wiebking U, Hankemeier S (2011) Leg lengthening using intramedullary skeletal kinetic distractor: results of 57 consecutive applications. Injury. 42(2):150-155

26. Lee DH, Ryu KJ, Song HR, Han SH (2014) Complications of the intramedullary skeletal kinetic distractor (ISKD) in distraction osteogenesis. Clin Orthop Relat Res 472(12):3852-3859

27. Baumgart R, Betz A, Schweiberer L (1997) A fully implantable motorized intramedullary nail for limb lengthening and bone transport. Clin Orthop Relat Res 343:135-143

28. Singh S, Lahiri A, lqbal M (2006) The results of limb lengthening by callus distraction using an extending intramedullary nail (Fitbone) in nontraumatic disorders. J Bone Jt Surg Br 88:938-942 
29. Al-Sayyad MJ (2012) Lower limb lengthening and deformity correction using the fitbone motorized nail system in the adolescent patient. J Pediatr Orthop B 21(2):131-136

30. Krieg AH, Lenze U, Speth BM, Hasler CC (2011) Intramedullary leg lengthening with a motorized nail. Acta Orthop 82(3):344-350 (Epub 2011 May 11)

31. Kirane YM, Fragomen AT, Rozbruch SR (2014) Precision of the PRECICE internal bone lengthening nail. Clin Orthop Relat Res 472(12):3869-3878

32. Hasler CC, Krieg AH (2012) Current concepts of leg lengthening. J Child Orthop 2012(6):89-104

33. Lobst C (2015) Advances in pediatric limb lengthening, Part II. JBJS Rev 3(9):e4:1-7

34. D'Ambrosi R, Barbato A, Caldarini C, Biancardi E, Facchini RM (2016) Gradual ulnar lengthening in children with multiple exostoses and radial head dislocation: results at skeletal maturity. J Child Orthop 10(2):127133. https://doi.org/10.1007/s11832-016-0718-8 (Epub 2016 Feb 24)

35. Dahl MT, Gulli B, Berg T (1994) Complications of limb lengthening. A learning curve. Clin Orthop Relat Res (301):10-18

36. Lascombes P, Popkov D, Huber H, Haumont T, Journeau P (2012) Classification of complications after progressive long bone lengthening: proposal for a new classification. Orthop Traumatol Surg Res 98(6):629-637

37. Dahl MT1, Gulli B, Berg T (1994) Complications of limb lengthening. A learning curve. Clin Orthop Relat Res (301):10-18

38. Bukva B, Vrgoč G, Rakovac I, Dučić S, Sindik J, Čoklo M, Marinović M, Bakota B (2015) Complications in leg lengthening using an llizarov external fixator and intramedullary alignment in children: comparative study during a fourteen-year period. Injury 46(Suppl 6):S48-S51

39. Castelein S, Docquier P (2016) Complications associated with bone lengthening of the lower limb by callotasis. Acta Orthopædica Belgica 82(4):806-813

40. Reitenbach E, Rödl R, Gosheger G, Vogt B, Schiedel F (2016) Deformity correction and extremity lengthening in the lower leg: comparison of clinical outcomes with two external surgical procedures. SpringerPlus 5(2003):1-9

41. Manggala Y, Chayanin Angthong C, Primadhi A, Kungwan S (2017) The deformity correction and fixator assisted treatment using llizarov versus Taylor spatial frame in the foot and ankle. Orthop Rev 9:7337

42. Novikov KI, Subramanyam KN, Muradisinov SO, Novikova OS, Kolesnikova ES (2014) Cosmetic lower limb lengthening by llizarov apparatus: what are the risks? Clin Orthop Relat Res. 472:3549-3556

43. Guerreschi F, Tsibidakis $H$ (2016) Cosmetic lengthening: what are the limits? J Child Orthop 10(6):597-604

44. Fragomen KA, Robert Rozbruch R (2016) Prevention of pin site infection in external fixation: a review of the literature. Strateg Trauma Limb Reconstr 11:75-85

45. Makhdom AM, Cartaleanu AS, Rendon JS, Villemure I, Hamdy RC (2015) The accordion maneuver: a noninvasive strategy for absent or delayed callus formation in cases of limb lengthening. Adv Orthop 1-8

46. Song SH, Kim SE, Agashe MV, Lee H, Refai MA, Park YE, Choi HJ, Park JH, Song HR (2012) Growth disturbance after lengthening of the lower limb and quantitative assessment of physeal closure in skeletally immature patients with achondroplasia. J Bone Jt Surg Br 94(4):556-563

47. Kadono I, Kitoh H, Mishima K, Matsushita M, Sato K, Kako M, Ishiguro N (2018) Changes in the range of motion of the lower limb joints during extensive tibial lengthening in achondroplasia. J Pediatr Orthop B 27(6):535-540

48. Chilbule SK, Dutt V, Madhuri V (2016) Limb lengthening in achondroplasia. Indian J Orthop. 50(4):397-405

49. Ko KR, Shim JS, Chung CH, Kim JH (2019) Surgical results of limb lengthening at the femur, tibia, and humerus in patients with achondroplasia. Clin Orthop Surg. 11(2):226-232
50. Al Kaissi A, Farr S, Ganger R, Hofstaetter GH, Klaushofer K, Grill F (2013) Treatment of varus deformities of the lower limbs in patients with achondroplasia and hypochondroplasia. Open Orthop J 7:33-39

51. Kim SJ, Balce GC, Agashe MV, Song SH, Song HR (2012) Is bilateral lower limb lengthening appropriate for achondroplasia? Midterm analysis of the complications and quality of life. Clin Orthop Relat Res 470(2):616-621

52. Herzenberg JE, Paley D (2007) Limb lengthening and reconstruction surgery. In: Rozbruch RS, Ilizarov S (eds) Stature lengthening in skeletal dysplasia. Informa Healthcare, New York, pp 575-596

53. Donaldson J, Aftab S, Bradish S (2015) Achondroplasia and limb lengthening: results in a UK cohort and review of the literature. J Orthop 12:31-34

54. Karthik V, Nimbalkar S (2017) Cosmetic limb lengthening in a patient of normal stature: ethical considerations. Indian J Med Ethics 2(1):45-48

55. Reinker KA (2014) CORR Insights ${ }^{\circledR}$ : cosmetic lowerlimb lengthening by llizarov apparatus: what are the risks? Clin Orthop Relat Res 472(11):3557-3558

56. Burghardt RD, Yoshino K, Kashiwagi N, Yoshino S, Bhave A, Paley D, Herzenberg JE (2015) Bilateral double level tibial lengthening in dwarfism. J Orthop 12(4):242-247

57. Kocaoglu M, Bilen FE, Eralp IL, Yumrukcal F (2015) Results of cosmetic lower limb lengthening by the lengthening over nail technique. Acta Orthop Belg 83:231-244

58. Far S, Mindler G, Ganger R, Girsch W (2016) Bone lengthening in the pediatric upper extremity. J Bone Jt Surg Am 98(17):1490-1503

59. Damsin JP, Ghanem I (2000) Upper limb lengthening. Hand Clin 16(4):685-701

60. Hosny GA (2016) Humeral lengthening and deformity correction. J Child Orthop 10(6):585-592. https://doi.org/10.1007/s11832-016-0789-6

61. Hosny GA (2005) Humeral lengthening in children and adolescents. J Pediatr Orthop B 14(6):439-443

62. Hammouda Al, Standard SC, Robert Rozbruch S, Herzenberg JE (2017) Humeral lengthening with the PRECICE magnetic lengthening nail. HSS J 13(3):217-223

63. Hosny GA, Kandel WA (2013) Treatment of posttraumatic radial club hand with distraction lengthening. Ann Plast Surg 71(5):489-492. https://doi. org/10.1097/SAP.0b013e3182a79596

64. Hosny GA (2015) Forearm lengthening. J Orthop Traumatol. 6:132-137

65. Hill RA, Ibrahim T, Mann HA, Siapkara A (2011) Forearm lengthening by distraction osteogenesis in children: a report of 22 cases. J Bone Jt Surg Br 93(11):1550-1555

66. Hosny GA, Kandel WA (2012) Distraction lengthening by callotasis of traumatically shortened bones of the hand. J Trauma Acute Care Surg. 72(6):1676-1680

67. Ding Z, Zhu X, Fu K, Zheng X (2017) Digital lengthening to treat finger deficiency: an experience of 201 digits in 104 patients. Biomed Res Int 2017:4934281-4934285

68. Lee DH, Kim S, Lee JW, Park H, Kim TY, Kim HW (2017) A comparison of the device-related complications of intramedullary lengthening nails using a new classification system. BioMed Res Int 2017:8032510. https:// doi.org/10.1155/2017/8032510

\section{Publisher's Note}

Springer Nature remains neutral with regard to jurisdictional claims in published maps and institutional affiliations. 